\title{
Testosterone therapy and prostate cancer
}

\author{
Alexander W. Pastuszak ${ }^{1,2}$, Katherine M. Rodriguez ${ }^{3}$, Taylor M. Nguyen ${ }^{3}$, Mohit Khera $^{2}$ \\ ${ }^{1}$ Center for Reproductive Medicine, ${ }^{2}$ Scott Department of Urology, Baylor College of Medicine, Houston, TX, USA; ${ }^{3}$ Baylor College of Medicine, \\ Houston, TX, USA \\ Contributions: (I) Conception and design: All authors; (II) Administrative support: AW Pastuszak, M Khera; (III) Provision of study materials or \\ patients: All authors; (IV) Collection and assembly of data: All authors; (V) Data analysis and interpretation: AW Pastuszak, TM Nguyen, KM \\ Rodriguez, M Khera; (VI) Manuscript writing: All authors; (VII) Final approval of manuscript: All authors. \\ Correspondence to: Mohit Khera, MD, MBA, MPH. Associate Professor, Scott Department of Urology, Baylor College of Medicine, 7200 Cambridge \\ St, 10th Floor, Houston, TX 77005, USA. Email: mkhera@bcm.edu.
}

\begin{abstract}
The use of exogenous testosterone to treat hypogonadism in the men with a history of prostate cancer $(\mathrm{CaP})$ remains controversial due to fears of cancer recurrence or progression. Due to the detrimental impact of hypogonadism on patient quality of life, recent work has examined the safety of testosterone therapy (TTh) in men with a history of CaP. In this review, we evaluate the literature with regards to the safety of TTh in men with a history of CaP. TTh results in improvements in quality of life with little evidence of biochemical recurrence or progression in men with a history of $\mathrm{CaP}$, or de novo cancer in unaffected men. An insufficient amount of evidence is currently available to truly demonstrate the safe use of TTh in men with low risk CaP. In men with high-risk cancer, more limited data suggest that TTh may be safe, but these findings remain inconclusive. Despite the historic avoidance of TTh in men with a history of $\mathrm{CaP}$, the existing body of evidence largely supports the safe and effective use of testosterone in these men, although additional study is needed before unequivocal safety can be demonstrated.
\end{abstract}

Keywords: Hypogonadism; testosterone; hormone replacement; prostate cancer $(\mathrm{CaP})$; prostatectomy; radiation therapy

Submitted Jul 05, 2016. Accepted for publication Jul 06, 2016.

doi: $10.21037 /$ tau.2016.08.17

View this article at: http://dx.doi.org/10.21037/tau.2016.08.17

\section{Introduction}

Male hypogonadism is defined as the presence of both low serum testosterone levels as well as symptoms that can include decreased libido, erectile dysfunction, loss of vitality, loss of lean muscle and bone density, fatigue, anemia and depression (1). The prevalence of hypogonadism has proven difficult to accurately determine, with the highest reported prevalence reported in 2006 when Mulligan et al. found that $40 \%$ of men over age 45 had symptomatic hypogonadism (2). Alternatively, the European Male Aging Study (EMAS) reported a prevalence of only $2.1 \%$, and the Boston Area Community Health Study (BACHS) estimated the prevalence of hypogonadism to be $5.6 \%$ among men $30-79$ years old $(3,4)$. Importantly, these studies incorporated both the presence of low testosterone levels as well as symptoms as part of the definition of hypogonadism. Prostate cancer $(\mathrm{CaP})$ is also most common among older men and accounts for one of every five cancer diagnoses in men (5). Mortality from $\mathrm{CaP}$ has dropped by over $50 \%$ in the past two decades, with an increase in survivorship that is significantly higher than the overall increase in cancer survivorship. This improved survivorship in men with $\mathrm{CaP}$ is primarily attributed to earlier cancer detection and treatment, and is leading to growing population of $\mathrm{CaP}$ survivors; it is estimated that $20 \%$ of all cancer survivors are $\mathrm{CaP}$ survivors (6).

Over the past decade, the use of testosterone therapy (TTh) has dramatically increased. Between 2001-2011 the number of testosterone prescriptions tripled, with increases among all age groups. Baillargeon and colleagues found that $3.75 \%$ of the U.S. male population over 65 years old had been prescribed some form of TTh (7). This increase in 
prescribing practices is in part due to the known benefits of therapy, which can decrease mortality, improve lipid parameters, decrease body fat, and improved sexual function (8-10). The negative physiological sequelae of hypogonadism are also well established, and include bone reabsorption, which can lead to osteoporosis and osteopenia; TTh can normalize bone density (11-13). Multiple studies have also shown that testosterone has important immunomodulatory effects, including regulation of neutrophils and monocytes (14-17). Along with the benefits of TTh, several potential risks have been identified. Among these, the most discussed are the potential adverse cardiovascular $(\mathrm{CV})$ effects of TTh and the impact of testosterone on CaP. Numerous studies have reported a relationship between $\mathrm{TTh}$ and $\mathrm{CV}$ risk, with studies observing an increased risk of $\mathrm{CV}$ events in men with both low and high testosterone levels. Most recently, a handful of studies have observed a positive correlation between testosterone levels and CV events, especially in older men, and have ultimately led to changes in testosterone labeling (18-21). More recently, Baillargeon and colleagues found that the risk of $\mathrm{CV}$ events was the same in both hypogonadal men treated and not treated with TTh. Upon further examination, however, a modest decrease in $\mathrm{CV}$ risk was observed in the testosterone treated cohort $(22,23)$.

For decades, the use of TTh in men with a history of $\mathrm{CaP}$ has been controversial. The seminal 1941 study by Drs. Charles Huggins and Clarence Hodges found that castration resulted in regression of metastatic $\mathrm{CaP}$, implicating androgens in the $\mathrm{CaP}$ growth (24). Subsequent work supported a role for testosterone in recurrence or progression of existing $\mathrm{CaP}$, especially in the setting of advanced $\mathrm{CaP}(25,26)$. As such, an androgen dependent model of $\mathrm{CaP}$ remains the main objection to TTh in men with a history of $\mathrm{CaP}$ (27). However, clinical studies have failed to show a persuasive link between $\mathrm{CaP}$ and $\mathrm{TTh}$ that would limit the treatment of hypogondal men with a history of $\mathrm{CaP}$. With an aging population, increasing $\mathrm{CaP}$ survivorship and the quality of life that can be restored with $\mathrm{TTh}$, TTh is worth considering in CaP survivors. In this review, we examine the literature with regards to the risk of $\mathrm{CaP}$ as a function of serum testosterone levels, as well as what is known regarding the safety of TTh in men with a history of $\mathrm{CaP}$.

\section{Methods}

A literature search was conducted using PubMed to identify relevant, current studies as well as historical perspectives on the data and attitudes examining TTh in the setting of CaP. Search terms used included: "prostate cancer", "hypogonadism", "testosterone replacement therapy", "TTh", "active surveillance (AS)", "radical prostatectomy", and "radiation therapy".

\section{CaP and low serum testosterone}

The link between low endogenous testosterone levels and $\mathrm{CaP}$ has been extensively studied. Men with low endogenous testosterone levels have increased rates and severity of $\mathrm{CaP}$ at diagnosis, including extraprostatic invasion (28). The first study to recognize this was published in 1996 by Morgentaler et al., in which the authors identified $\mathrm{CaP}$ in $14 \%$ of 77 men with low serum testosterone levels, a normal digital rectal examination (DRE) and a PSA $<4.0 \mathrm{ng} / \mathrm{mL}$. Though the small sample size limited the generalizability of these initial results, the relationship between endogenous testosterone levels has been examined repeatedly over the past two decades (Table 1) (29). In 2006, Morgentaler et al. examined 345 hypogonadal men with a PSA $<4.0 \mathrm{ng} / \mathrm{mL}$, and found $\mathrm{CaP}$ in $21 \%$ of men with a testosterone level of $\leq 250 \mathrm{ng} / \mathrm{dL}$. In contrast, only $12 \%$ of men with a testosterone level $>250 \mathrm{ng} / \mathrm{dL}$ were found to have $\mathrm{CaP}(\mathrm{P}=0.04)$ (33). A 2013 prospective study of 206 men with benign prostatic hyperplasia $(\mathrm{BPH})$ or $\mathrm{CaP}$ found that low serum testosterone levels (less than $240 \mathrm{ng} / \mathrm{dL}$ ) were an independent predictor of $\mathrm{CaP}$ risk $[\mathrm{P}=0.004$ with an OR for CaP of 0.7 (95\% CI: 0.55-0.89)] (30). In 2010, Shin $e t$ al. studied 568 men undergoing prostate biopsy and divided them into low $(<385 \mathrm{ng} / \mathrm{dL})$ and high $(>385 \mathrm{ng} / \mathrm{dL})$ testosterone groups. Using multivariate regression analysis to compare these groups, the authors found a significantly higher incidence of $\mathrm{CaP}$ in the low testosterone group (38.9\% vs. $29.5 \%, \mathrm{P}=0.018)$. In addition to low serum testosterone levels, the study identified increasing age, high PSA, and low prostate volume as factors associated with increased $\mathrm{CaP}$ risk (31).

Low serum testosterone has also been linked to more aggressive, higher-grade CaP. In 2000, Hoffman and colleagues retrospectively analyzed 117 men with CaP. Men with low serum testosterone levels $(<300 \mathrm{ng} / \mathrm{dL})$ were found to have a higher number of positive cores on biopsy ( $43 \%$ vs. $22 \%, \mathrm{P}=0.013$ ) and were more likely to have Gleason sum 8 or greater disease ( 7 of $64 v s .0$ of $48, P=0.025$ ) when compared with men with normal testosterone levels (34). A similar retrospective analysis of 137 men with $\mathrm{CaP}$ showed that high serum testosterone is correlated with lower stage 
Table 1 Studies examining the relationship between low endogenous testosterone levels and prostate cancer

\begin{tabular}{|c|c|c|c|c|}
\hline References & Number of pts & Study type & Endogenous TTh level & CaP outcomes \\
\hline \multirow[t]{2}{*}{ Mearini et al. (30) } & 206 & Prospective & $\leq 2.4 \mathrm{ng} / \mathrm{mL}$ & $\begin{array}{l}14.2 \% \text { of patients had clinically locally } \\
\text { advanced or metastatic CaP, and } 57.1 \% \\
\text { have a pathological locally advanced } \mathrm{CaP}\end{array}$ \\
\hline & & & $\leq 0.5 \mathrm{ng} / \mathrm{mL}$ & $\begin{array}{l}40 \% \text { of patients have clinically locally } \\
\text { advanced or metastatic CaP, and } 60 \% \\
\text { has a pathological locally advanced } \mathrm{CaP}\end{array}$ \\
\hline Shin et al. (31) & 568 & Prospective & $<3.85 \mathrm{ng} / \mathrm{mL}$ & $\begin{array}{l}\text { CaP incidence } 38.0 \% \text { (vs. } 29.5 \% \text { high } \\
\text { testosterone group) }\end{array}$ \\
\hline Karamanolakis et al. (32) & 718 & Prospective & $<3.0 \mathrm{ng} / \mathrm{mL}$ & CaP incidence $30 \%(29 / 97)$ \\
\hline Morgantaler et al. (33) & 345 & Retrospective & $<250 \mathrm{ng} / \mathrm{dL}$ & $\begin{array}{l}\text { CaP incidence } 21 \% \text { (vs. } 12 \% \text { in men with } \\
T>250 \mathrm{ng} / \mathrm{dL} \text { ) }\end{array}$ \\
\hline García-Cruz et al. (35) & 137 & Prospective & $<346 \mathrm{ng} / \mathrm{dL}$ & $\begin{array}{l}\text { Tumor burden } 53 \% \text { (vs. } 32 \% \text { in men with } \\
\mathrm{T}>346 \mathrm{ng} / \mathrm{dL} \text { ); tumor bilaterality } 50 \% \text { (vs. } \\
25.5 \% \text { in men with } \mathrm{T}>346 \mathrm{ng} / \mathrm{dL} \text { ) }\end{array}$ \\
\hline Isom-Batz et al. (36) & 326 & Retrospective & $<385$ ng/dL & $\begin{array}{l}\text { Associated with advanced pathological } \\
\text { stage (OR 2.3, } 95 \% \mathrm{Cl}: 1.1-5.0 ; \mathrm{P}=0.03)\end{array}$ \\
\hline Lane et al. (37) & 455 & Prospective & $<220 \mathrm{ng} / \mathrm{dL}$ & $\begin{array}{l}\text { Higher frequency of Gleason } 4-5 \text { disease } \\
\text { (OR } 2.4,95 \% \mathrm{Cl} \text { : } 1.01-5.7 ; \mathrm{P}=0.48 \text { ) }\end{array}$ \\
\hline Botto et al. (38) & 431 & Prospective & $<3 \mathrm{ng} / \mathrm{mL}$ & $\begin{array}{l}\text { Higher frequency of Gleason } 4 \text { disease } \\
(47 \% \text { vs. } 28 \%)\end{array}$ \\
\hline
\end{tabular}

pts, patients; CaP, prostate cancer; TTh, testosterone therapy; T, testosterone; OR, odds ratio.

disease based on DRE $(\mathrm{P}=0.02)$ and PSA $(\mathrm{P}=0.05)$. Lower serum testosterone was also correlated with higher rates of bilateral disease $(\mathrm{P}<0.01)(35)$. Yet another similarly designed study examined the pretreatment hormonal status of 326 men who underwent radical prostatectomy and examined biochemical recurrence (PSA $>0.4 \mathrm{ng} / \mathrm{mL}$ with a documented increase after treatment). While the study found no relationship between PSA and testosterone levels $(\mathrm{P}=0.4)$, low testosterone was found to inversely correlate with pathological stage, clinical stage and biopsy grade $(\mathrm{P}=0.01)$ (36).

Recent prospective studies have also shown that low pretreatment testosterone level is a predictor of higher Gleason score. A 2008 study examining 455 men found that low serum testosterone was not predictive of biochemical recurrence, tumor volume or disease progression, but that it was associated with Gleason 4-5 disease [odds ratio (OR) 2.4, 95\% CI: $1.0-5.7 ; \mathrm{P}=0.048$ ] (37). While the literature mainly supports hypogonadism as a risk factor for $\mathrm{CaP}$ and increased severity of disease, controversy still remains in the absence of large prospective, controlled studies. A retrospective analysis of 673 men with $\mathrm{CaP}$ showed hypogonadism to only be predictive of seminal vesicle invasion and did not show a relationship between pretreatment hypogonadism and a higher incidence of $\mathrm{CaP}$ (39). Lastly, beyond incidence and severity, low pretreatment testosterone has been linked to an increased likelihood of positive surgical margins after radical prostatectomy $(\mathrm{P}=0.026)(40)$. 
Table 2 Studies examining the relationship between normal and high serum testosterone levels and prostate cancer

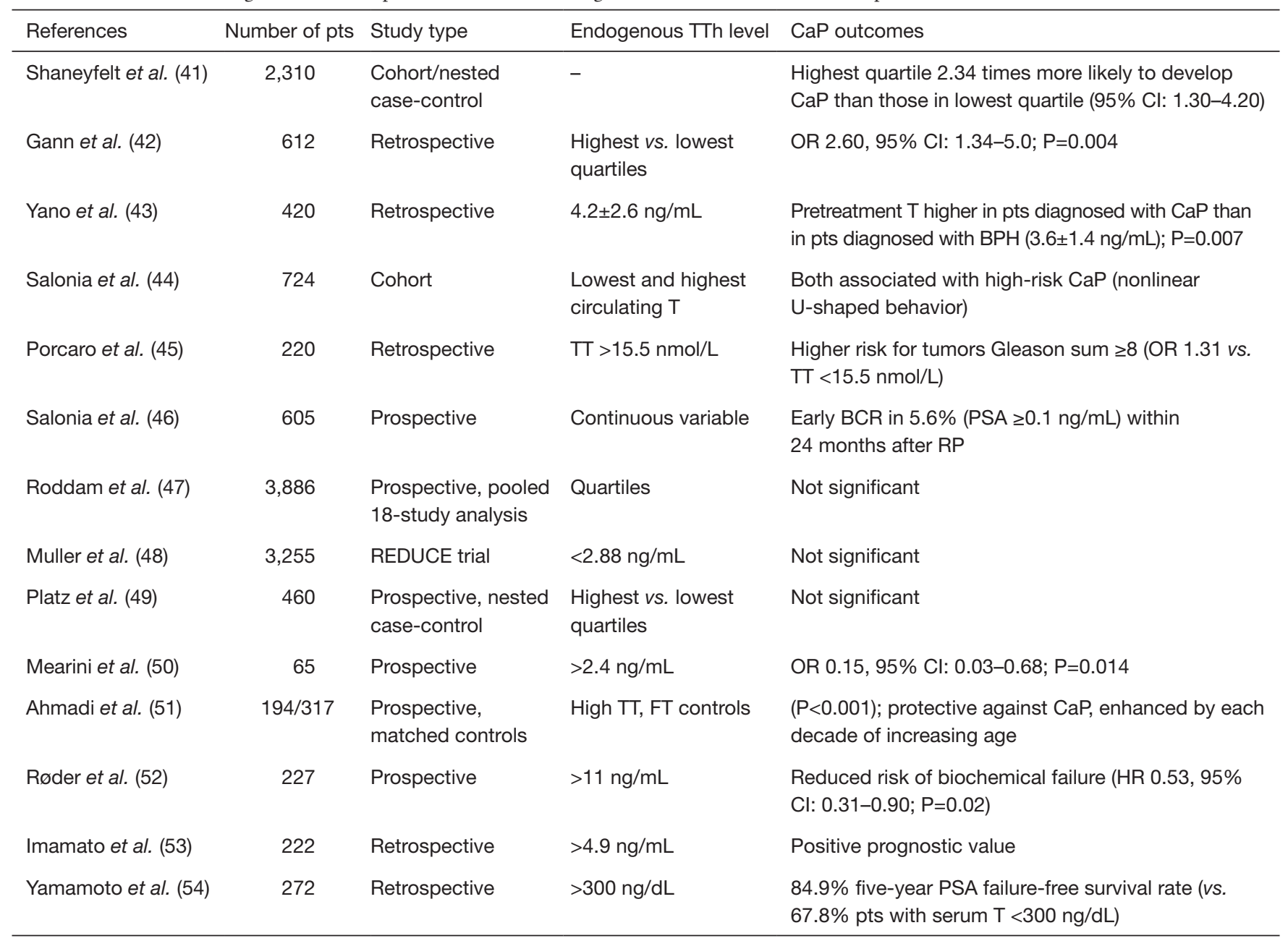

pts, patients; CaP, prostate cancer; TTh, testosterone therapy; OR, odds ratio; T, testosterone; TT, total testosterone; FT, free testosterone; $\mathrm{BCR}$, biochemical recurrence; PSA, prostate specific antigen.

\section{CaP and normal or high serum testosterone levels}

Studies examining the relationship between normal and high pretreatment serum testosterone levels and $\mathrm{CaP}$ have yielded often conflicting results (Table 2). A number of studies have reported an increased risk of $\mathrm{CaP}$ with high pretreatment serum testosterone levels. In 1996, Gann et al. reported a positive association between men in the highest quartile of testosterone levels and an increased risk of $\mathrm{CaP}$ (42). Similarly, a meta-analysis published in 2000 found that when stratified by pretreatment testosterone levels, men in the highest quartile were 2.34 times more likely to develop CaP (95\% CI: 1.30-4.20). While this meta-analysis adjusted for BMI, age and serum hormone levels, it only incorporated data from two studies (41). A 2007 study enrolling 420 men found that while there was no significant relationship between pretreatment testosterone levels and prostate biopsy results, men with PSA $<10 \mathrm{ng} / \mathrm{mL}$ eventually diagnosed with $\mathrm{CaP}$ (mean T $420 \pm 260 \mathrm{ng} / \mathrm{dL}$ ) had higher serum testosterone levels than men diagnosed with benign prostatic disease (mean T $360 \pm 140 \mathrm{ng} / \mathrm{dL}$ ) $(\mathrm{P}=0.007)(43)$.

The relationship between Gleason score and high serum testosterone levels has also been examined. In 2014, Porcaro et al. found a relationship between men with higher normal pretreatment testosterone levels $(\mathrm{T}>447 \mathrm{ng} / \mathrm{dL})$ and Gleason sum $\geq 8$ disease $(\mathrm{P}=0.0004)$ when compared to men with lower testosterone (45). In 2016, Porcaro et al. found 
that high testosterone levels predicted an increased risk of Gleason score upgrading (OR, 1.06; $\mathrm{P}=0.027)$ (55).

In contrast to the above findings, several studies have found no relationship, or even a protective relationship, between high testosterone levels and $\mathrm{CaP}$ risk. The Endogenous Hormones and CaP Collaborative Group used conditional logistic regression to assess 18 prospective studies that included 3,886 men with incident $\mathrm{CaP}$ and 6,438 controls. No associations between the risk of $\mathrm{CaP}$ and serum testosterone concentrations were identified (47). The Reduction by Dutasteride of Prostate Cancer Events (REDUCE) trial and Platz et al. (retrospective review of 460 men) both reported a lack of association between normal or high testosterone and $\mathrm{CaP}$ incidence $(48,49)$. A handful of studies have observed a decreased risk of $\mathrm{CaP}$ in the setting of high testosterone levels. In 2004, Stattin et al. conducted a case-control study of 708 men with $\mathrm{CaP}$ and found a modest but significant decrease in $\mathrm{CaP}$ risk among men with higher pretreatment testosterone levels $(\mathrm{P}=0.05)$ (56). Two similarly designed studies also reported that men with higher testosterone levels had a lower risk of $\mathrm{CaP}(50,51)$. A lower risk of biochemical recurrence and better prognosis for both localized and metastatic $\mathrm{CaP}$ after radical prostatectomy have also been observed in men with higher pretreatment testosterone levels (52-54).

\section{Prostate specific antigen (PSA) and testosterone levels}

The secretion of PSA and growth of $\mathrm{CaP}$ are under androgenic control. As such, androgen deprivation remains a major component of advanced $\mathrm{CaP}$ treatment (57). However, changes in PSA in vivo do not linearly correlate with serum testosterone levels. A 1998 study found no significant change in PSA levels in 31 healthy volunteers 21-39 years old after administration of either 100,250 or $500 \mathrm{mg}$ testosterone for 15 weeks at any dose, supporting an androgen receptor (AR) saturation point, above which no further increases in PSA or CaP growth are observed (58). In healthy men, the AR saturation point is thought to be at a serum testosterone concentration of 150-200 ng/dL (59). Among men with castrate serum testosterone levels, a rise in testosterone levels correlates with a rise in PSA, but only until the androgen receptor is saturated (60). Studies aimed at correlating androgen levels and PSA have had limited success. Mearini et al. set out to determine whether serum testosterone levels could augment the use of PSA levels in distinguishing $\mathrm{CaP}$ from $\mathrm{BPH}$ in men in whom $\mathrm{CaP}$ was suspected due to their elevated PSA. Testosterone level was identified as an independent predictor of $\mathrm{CaP}$ risk, as both a continuous and binary variable with sensitivity and specificity varying as a function of testosterone thresholds established in the analysis. For testosterone levels below $240 \mathrm{ng} / \mathrm{dL}$, sensitivity and specificity of predicting $\mathrm{CaP}$ were $32 \%$ and $91.3 \%$, respectively. For testosterone levels below $50 \mathrm{ng} / \mathrm{dL}$, sensitivity and specificity were $9.4 \%$ and $99 \%$, respectively (30).

\section{Models to explain clinical findings}

As a result of the findings of Huggins and Hodges in 1941, treatment of hypogonadal men with a history of $\mathrm{CaP}$ has remained controversial. However, since the early 1990's, both in vitro and in vivo studies have largely argued against prior work supporting $\mathrm{CaP}$ growth in the setting of rising testosterone levels. Work over the past two decades has yielded conflicting results and has shown that the relationships between androgen levels, healthy prostate tissue and $\mathrm{CaP}$ is more complex than originally thought. Two recent models that have been proposed to explain the more recent clinical findings are the prostate saturation and time-dependence models.

The prostate saturation model was first alluded to in 1981 by Fowler and Whitmore, who concluded that normal serum testosterone levels may not be correlated with maximal $\mathrm{CaP}$ growth and that growth only varied with androgens at sub-physiologic levels (26). Morgentaler and Traish sought to reconcile why low testosterone levels resulted in regression of $\mathrm{CaP}$ but high levels could not consistently be linked to $\mathrm{CaP}$ growth or spread. They postulated that because tumor growth varied with testosterone levels only in the setting of castrate testosterone levels, and not in eugonadal men, that this may be related to the saturation point of the AR, and that any stimulation of prostate tissue would cease when the AR saturation point had been reached (61). These authors published a literature review in 2009 that supported their model and suggested the AR saturation point was below the generally accepted $300 \mathrm{ng} / \mathrm{dL}$ threshold for clinical hypogonadism (62). Overall, however, there are a few studies that support the prostate saturation model (58). In 2014, Morgentaler et al. published a double-blind placebo-controlled study of 274 hypogonadal men. One of the relevant factors predicting an increase in PSA during testosterone gel treatment was a baseline testosterone level of $<250 \mathrm{ng} / \mathrm{dL}$. No significant variation in PSA levels in men with baseline testosterone $>250 \mathrm{ng} / \mathrm{dL}$ was observed (63). A similar study enrolling 451 men found comparable results and concluded 
that physicians should exercise caution when treating hypogonadal men with very low testosterone levels (64). There is also support for this prostate saturation model in vitro using the androgen-responsive $\mathrm{CaP}$ tumor cell line, LnCaP. Bologna et al. found that the growth rate of these cells was only enhanced at the lowest $\mathrm{T}$ concentrations $(0.001 \mu \mathrm{M})$ and that there was a modest but statistically insignificant protective effect at higher concentrations (65). Using the same cell line, Arnold et al. found that cell proliferation increased at low $\mathrm{T}$ concentrations but that at higher concentrations even logarithmic increases in $\mathrm{T}$ could not enhance growth (66).

The time-dependence model was initially presented in 2012 by Salonia et al. This model was developed based on the observation that an increased risk of $\mathrm{CaP}$ was observed both at near-castrate as well as high serum testosterone levels. The authors concluded that the relationship between $\mathrm{CaP}$ and androgen levels followed a non-linear u-shaped distribution. Salonia et al. dubbed this the time dependence theory because they postulated that the healthy endocrine tissue relied on temporal stimulation of different androgen levels and that these fluctuations were absent in men who went on to develop $\mathrm{CaP}(28,44)$. Broad support for the time-dependence theory does not currently exist, in large part because the relationship between high endogenous testosterone levels and $\mathrm{CaP}$ remains unclear.

Both the prostate saturation and time-dependence models account for the observation that $\mathrm{CaP}$ growth in culture is androgen-dependent at low levels. This is clinically relevant because these levels $(0.23 \mathrm{ng} / \mathrm{mL}$ and between 1 and $2 \mathrm{ng} / \mathrm{mL}$ for the cell lines $\mathrm{LnCaP}$ and MDA PCa 2b, respectively) are at the low end of physiologic testosterone levels (67). This is thought to explain $\mathrm{CaP}$ recurrence after androgen deprivation therapy (ADT) as the androgen levels normalize from castrate levels after treatment (68). In men with androgen-sensitive cancers, keeping androgen levels low is the standard of care despite the tradeoff of hypogonadal symptoms (69). Most men who undergo ADT will eventually develop castration-resistant prostate cancer (CRPC). Many cellular mechanisms have been attributed to this phenomenon including: increased expression of both wild type and ligand-independent AR variants, AR gene amplification, and AR mutations (70-74).

While cells can adapt to androgen deprivation well, even CRPC cells are inhibited by supraphysiologic androgen levels $(75,76)$. Hatzoglou et al. found dose-dependent inhibition of cell growth could be induced using testosterone, leading to increased apoptosis and decreased prostate cell migration, adhesion, and invasiveness in human LNCaP cells (77). Mechanistically, supraphysiologic androgen levels facilitate nuclear stabilization of ligand-bound AR, which leads to apoptosis by inhibiting DNA relicensing $(78,79)$. High androgen levels can also cause lethal double stranded DNA breaks, which can be pharmacologically exploited using single-agent oral etoposide, an inhibitor of topoisomerase II $\beta$ and DNA repair (80). This in vitro finding led to a 2015 pilot study using bipolar androgen therapy (BAT) to treat metastatic CaP. Fourteen patients with metastatic CRPC were given testosterone cypionate (400 $\mathrm{mg}$ intramuscular) and etoposide (100 $\mathrm{mg}$ oral daily) to rapidly bring them from castrate to supraphysiologic testosterone levels; this cycle was repeated three times. After BAT, the patient's testosterone levels were brought back to castrate levels. Astonishingly, 7 of 14 patients had PSA decline in response to AR-directed therapy (such as abiraterone, enzalutamide, or bicalutamide) given after BAT, suggesting that BAT could re-sensitize patients to therapy (81). Additional in vitro evidence supports the efficacy of BAT therapy. Song and Khera demonstrated a dose-dependent inhibition of $\mathrm{CaP}$ cell proliferation as physiologic androgen levels increased from the normal range, starting at $4 \mathrm{ng} / \mathrm{mL}$ testosterone (67). While many studies have examined the relationship between testosterone and $\mathrm{CaP}$, there are many ongoing limitations including: intra-individual variation in testosterone measurements, and clinical applicability of findings across age, race, $\mathrm{BMI}$ and $\mathrm{CaP}$ status.

\section{TTh across CaP treatment modalities}

\section{Radical prostatectomy}

Radical prostatectomy remains the preferred treatment modality in $\mathrm{CaP}$ patients under 70 years old with an aging population and increase in $\mathrm{CaP}$ survivorship, TTh after radical prostatectomy is an important area of investigation (82). Recent studies support the conclusion that TTh in men with a history of $\mathrm{CaP}$ is effective in treating hypogonadism without having a significant impact on $\mathrm{CaP}$ recurrence or progression.

A 2004 study by Kaufman and Graydon followed seven hypogonadal men started on TTh with a history of $\mathrm{CaP}$ treated with radical prostatectomy. After following the patients for 1-12 years, no $\mathrm{CaP}$ recurrence was observed, though the small sample size was a significant limitation of the work (83). In 2005, Agarwal and Oefelein followed ten men post radical prostatectomy recently started on TTh and found significant improvements in quality of 
life attributed to decreases in hot flashes and increases in energy without $\mathrm{CaP}$ recurrence or detectable increase in PSA after 19 months (84). In 2009 a retrospective review of 57 hypogonadal men ages 53-83 years old with $\mathrm{CaP}$ treated with radical prostatectomy who were started on TTh and followed for a mean of 36 months found no increase in PSA or biochemical recurrence despite an increase in mean testosterone levels from 255 to $459 \mathrm{ng} / \mathrm{dL}(\mathrm{P}<0.001)(85)$. More recently, Pastuszak et al. reviewed 103 hypogonadal men post radical prostatectomy treated with TTh and 49 non-hypogonadal men treated only with radical prostatectomy. Of the 103 hypogonadal men, 77 had nonhigh risk and 26 had high risk CaP. A clinically insignificant, but statistically significant increase in PSA levels was observed in the treatment group among both high and nonhigh risk patients; a similar PSA increase was not observed in the reference group. However, among men with high risk $\mathrm{CaP}$, four in the treatment group, in contrast with eight in the reference group, had a biochemical recurrence. The study concluded that although PSA levels could rise during TTh, this was not correlated with an increased incidence of $\mathrm{CaP}$ recurrence and that TTh could be appropriate in the treatment of hypogonadal men, even in the setting of high risk $\mathrm{CaP}(86)$.

\section{Radiation therapy}

The relationship between TTh in the setting of men with $\mathrm{CaP}$ treated using radiation therapy has also been studied. One study followed five men started on TTh after external beam radiation therapy (EBRT) observed small increases in PSA with no $\mathrm{CaP}$ recurrence, and emphasized the benefits of TTh including a reduction in hot flashes, increased energy and improved erectile function (87). A similar retrospective chart review that followed 31 hypogonadal men treated with TTh with a history of $\mathrm{CaP}$ treated with brachytherapy for 1.5-9 years observed an increase in PSA of $<0.5 \mathrm{ng} / \mathrm{mL}$ in 30 patients $(96.7 \%)$ and $<1 \mathrm{ng} / \mathrm{mL}$ in all patients with no $\mathrm{CaP}$ recurrences observed (88). A subsequent retrospective review of 13 hypogonadal men with $\mathrm{CaP}$ treated with brachytherapy or external beam radiation therapy on TTh found no significant increases in PSA or $\mathrm{CaP}$ recurrence. However, after a mean of 29.7 months follow-up, significant increases in testosterone levels were observed, along with improvements in hypogonadal symptoms (89). Interestingly, a 2014 study by Balbontin et al. following 20 men on TTh after brachytherapy reported a decrease in PSA from a baseline of 0.7 to $0.1 \mathrm{ng} / \mathrm{dL}$ after treatment $(\mathrm{P}<0.001)$. The authors also evaluated sexual function using the Sexual Health Inventory for Men (SHIM) questionnaire and observed a significant increase in scores from 16.1 at baseline to $22.1 \mathrm{in}$ men on TTh $(\mathrm{P}=0.002)(90)$. A 2015 retrospective study by Pastuszak et al. examined $\mathrm{CaP}$ outcomes by risk group in 98 hypogonadal men after radiation therapy treated with TTh. A low rate of biochemical recurrence ( $6.1 \%$ of the cohort) and a clinically insignificant rise in mean PSA were observed $[0.08 \mathrm{ng} / \mathrm{mL}$ at baseline to $0.09 \mathrm{ng} / \mathrm{mL}(\mathrm{P}=0.05)](91)$.

Though incompletely studied, in light of the above data, TTh should be considered in men after radiation therapy for $\mathrm{CaP}$ in conjunction with close surveillance. However, further study using randomized, controlled studies is needed.

\section{Patients on AS, at risk for developing CaP, or who have bigh risk CaP}

The American Cancer Society predicts 180,890 new cases of $\mathrm{CaP}$ in 2016, with $35-40 \%$ of those being low-risk (92). AS avoids overly aggressive treatment of low-risk $\mathrm{CaP}$ by periodically assessing the risk of $\mathrm{CaP}$ progression (93). Given the recent observations that do not demonstrate an increased risk of $\mathrm{CaP}$ incidence or progression in the setting of normal serum testosterone levels, TTh in the setting of $\mathrm{CaP}$ under AS, or in men at risk for developing CaP, may be reasonable. In 2003, Rhoden et al. studied 75 hypogonadal men who had been on TTh for at least a year. After prostate biopsy due to abnormal DRE or elevated PSA, 55 men had no evidence of prostatic intraepithelial neoplasia (PIN) and 20 had evidence of PIN with no overt cancer present. Men in both groups had similar PSA levels before TTh treatment. Small increases in PSA levels were also seen in men with and without PIN $(0.33 \pm 0.6$ and $0.25 \pm 0.6 \mathrm{ng} / \mathrm{dL}$, respectively, $\mathrm{P}>0.05)$ with only one man with PIN eventually developing CaP (94). In 2016, Kacker et al. found that when compared to 96 hypogonadal men on AS alone, the 28 hypogonadal men on AS and concurrent TTh had comparable CaP progression on biopsy over 3 years (95). Also in 2016, Ory et al. examined 82 hypogonadal men with $\mathrm{CaP}$ treated using either radiation therapy, radical prostatectomy, AS, cryotherapy or highintensity focused ultrasound and on TTh. Of the eight men on $\mathrm{AS}$, none required treatment of $\mathrm{CaP}$ after a mean follow-up of 27 months (96). Preliminary data examining men with advanced $\mathrm{CaP}$ on TTh also support efficacy of TTh without an increased risk of $\mathrm{CaP}$ progression. Ferreira et al. followed five hypogonadal patients with a history of advanced $\mathrm{CaP}$ on 
TTh. After 18 months, only one patient experienced a PSA increase and none of the men had CaP metastasis (97).

Few studies to date have studied TTh in men with active $\mathrm{CaP}$ and have reported predominantly positive outcomes in men with $\mathrm{CaP}$, with a common theme of caution. A 2016 review concluded that although the data on using TTh in men on AS are limited, preliminary studies show no, or minimal, increased risk compared to the quality of life improvements seen with treatment of hypogonadism (98). Conversely, a 2011 study following 25 men with $\mathrm{CaP}$ reported highly variable outcomes after starting TTh. The authors urged caution in treating these patients and concluded that an international registry to collect more data would be the only way to address whether TTh was safe in men with $\mathrm{CaP}(98,99)$. While the preliminary studies of TTh in the setting of AS appear to demonstrate the relatively safety of treating hypogonadism with TTh in this setting, it is important to note that none of these studies were randomized or controlled and that more work must be done before unequivocally determining the safety of such treatment.

\section{Conclusions}

The use of TTh in the setting of $\mathrm{CaP}$ remains controversial due to a lack of definitive, appropriately powered prospective controlled studies. However, available evidence supports the overall conclusion that TTh in patients with a history of both treated or untreated $\mathrm{CaP}$ is both safe and effective, particularly in men with low risk malignancies. TTh in men with a history of high-risk $\mathrm{CaP}$ is supported by small, retrospective studies that overall show no increased risk of $\mathrm{CaP}$ recurrence or progression in these men. In light of the available evidence, we recommend careful consideration of TTh in all men with an history of $\mathrm{CaP}$ while weighing the potential risks with the improvement in quality of life so clearly evidenced with TTh. Treatment of hypogonadism, especially in men with low risk $\mathrm{CaP}$ with significant impact on quality of life as a result of hypogonadism, is warranted. Men with high-risk $\mathrm{CaP}$ pose a more difficult scenario, but with appropriate surveillance, the available evidence supports the safe use of TTh in these men as well.

\section{Acknowledgements}

Funding: AWP is a K12 scholar supported by a Male Reproductive Health Research (MRHR) Career Development Physician-Scientist Award (Grant \# HD073917-01) from the
Eunice Kennedy Shriver National Institute of Child Health and Human Development (NICHD) Program.

\section{Footnote}

Conflicts of Interest: The authors have no conflicts of interest to declare.

\section{References}

1. Pastuszak AW, Gomez LP, Scovell JM, et al. Comparison of the Effects of Testosterone Gels, Injections, and Pellets on Serum Hormones, Erythrocytosis, Lipids, and ProstateSpecific Antigen. Sex Med 2015;3:165-73.

2. Mulligan T, Frick MF, Zuraw QC, et al. Prevalence of hypogonadism in males aged at least 45 years: the HIM study. Int J Clin Pract 2006;60:762-9.

3. Wu FC, Tajar A, Beynon JM, et al. Identification of lateonset hypogonadism in middle-aged and elderly men. $\mathrm{N}$ Engl J Med 2010;363:123-35.

4. Araujo AB, Esche GR, Kupelian V, et al. Prevalence of symptomatic androgen deficiency in men. J Clin Endocrinol Metab 2007;92:4241-7.

5. Siegel RL, Miller KD, Jemal A. Cancer statistics 2016. CA Cancer J Clin 2016;66:7-30.

6. Miller KD. editor. Excellent Care for Cancer Survivors: A Guide to Fully Meet Their Needs in Medical Offices and in the Community. Santa Barbara: Praeger, 2012.

7. Baillargeon J, Urban RJ, Ottenbacher KJ, et al. TRends in androgen prescribing in the united states 2001 to 2011. JAMA Intern Med 2013;173:1465-6.

8. Corona G, Isidori AM, Buvat J, et al. Testosterone supplementation and sexual function: a meta-analysis study. J Sex Med 2014;11:1577-92.

9. Isidori AM, Balercia G, Calogero AE, et al. Outcomes of androgen replacement therapy in adult male hypogonadism: recommendations from the Italian society of endocrinology. J Endocrinol Invest 2015;38:103-12.

10. Jones TH. Testosterone deficiency: a risk factor for cardiovascular disease? Trends Endocrinol Metab 2010;21:496-503.

11. Falahati-Nini A, Riggs BL, Atkinson EJ, et al. Relative contributions of testosterone and estrogen in regulating bone resorption and formation in normal elderly men. J Clin Invest 2000;106:1553-60.

12. Leder BZ, LeBlanc KM, Schoenfeld DA, et al. Differential effects of androgens and estrogens on bone turnover in normal men. J Clin Endocrinol Metab 2003;88:204-10. 
13. Zacharin MR, Pua J, Kanumakala S. Bone mineral density outcomes following long-term treatment with subcutaneous testosterone pellet implants in male hypogonadism. Clin Endocrinol (Oxf) 2003;58:691-5.

14. Corrales JJ, Almeida M, Burgo R, et al. Androgenreplacement therapy depresses the ex vivo production of inflammatory cytokines by circulating antigen-presenting cells in aging type-2 diabetic men with partial androgen deficiency. J Endocrinol 2006;189:595-604.

15. Liva SM, Voskuhl RR. Testosterone acts directly on CD4+ T lymphocytes to increase IL-10 production. J Immunol 2001;167:2060-7.

16. Malkin CJ, Pugh PJ, Jones RD, et al. The effect of testosterone replacement on endogenous inflammatory cytokines and lipid profiles in hypogonadal men. J Clin Endocrinol Metab 2004;89:3313-8.

17. Boje A, Moesby L, Timm M, et al. Immunomodulatory effects of testosterone evaluated in all-trans retinoic acid differentiated HL-60 cells, granulocytes, and monocytes. Int Immunopharmacol 2012;12:573-9.

18. Finkle WD, Greenland S, Ridgeway GK, et al. Increased risk of non-fatal myocardial infarction following testosterone therapy prescription in men. PLoS One 2014;9:e85805.

19. Spitzer M, Huang G, Basaria S, et al. Risks and benefits of testosterone therapy in older men. Nat Rev Endocrinol 2013;9:414-24.

20. Vigen R, O'Donnell CI, Barón AE, et al. Association of testosterone therapy with mortality, myocardial infarction, and stroke in men with low testosterone levels. JAMA 2013;310:1829-36.

21. Basaria S, Coviello AD, Travison TG, et al. Adverse events associated with testosterone administration. N Engl J Med 2010;363:109-22.

22. Baillargeon J, Urban RJ, Kuo YF, et al. Risk of Myocardial Infarction in Older Men Receiving Testosterone Therapy. Ann Pharmacother 2014;48:1138-44.

23. Desroches B, Kohn TP, Welliver C, et al. Testosterone therapy in the new era of Food and Drug Administration oversight. Transl Androl Urol 2016;5:207-12.

24. Huggins C, Hodges CV. Studies on prostatic cancer. I. The effect of castration, of estrogen and of androgen injection on serum phosphatases in metastatic carcinoma of the prostate. 1941. J Urol 2002;167:948-51; discussion 952.

25. Prout GR Jr, Brewer WR. Response of men with advanced prostatic carcinoma to exogenous administration of testosterone. Cancer 1967;20:1871-8.

26. Fowler JE Jr, Whitmore WF Jr. The response of metastatic adenocarcinoma of the prostate to exogenous testosterone. J Urol 1981;126:372-5.

27. Bhasin S, Cunningham GR, Hayes FJ, et al. Testosterone therapy in men with androgen deficiency syndromes: an Endocrine Society clinical practice guideline. J Clin Endocrinol Metab 2010;95:2536-59.

28. Klap J, Schmid M, Loughlin KR. The relationship between total testosterone levels and prostate cancer: a review of the continuing controversy. J Urol 2015;193:403-13.

29. Morgentaler A, Bruning CO 3rd, DeWolf WC. Occult prostate cancer in men with low serum testosterone levels. JAMA 1996;276:1904-6.

30. Mearini L, Zucchi A, Nunzi E, et al. Low serum testosterone levels are predictive of prostate cancer. World J Urol 2013;31:247-52.

31. Shin BS, Hwang EC, Im CM, et al. Is a Decreased Serum Testosterone Level a Risk Factor for Prostate Cancer? A Cohort Study of Korean Men. Korean J Urol 2010;51:819-23.

32. Karamanolakis D, Lambou T, Bogdanos J, et al. Serum testosterone: A potentially adjunct screening test for the assessment of the risk of prostate cancer among men with modestly elevated PSA values ( $>$ or $=3.0$ and $<10.0 \mathrm{ng} / \mathrm{ml}$ ). Anticancer Res 2006;26:3159-66.

33. Morgentaler A, Rhoden EL. Prevalence of prostate cancer among hypogonadal men with prostate-specific antigen levels of $4.0 \mathrm{ng} / \mathrm{mL}$ or less. Urology 2006;68:1263-7.

34. Hoffman MA, DeWolf WC, Morgentaler A. Is low serum free testosterone a marker for high grade prostate cancer? J Urol 2000;163:824-7.

35. García-Cruz E, Piqueras M, Huguet J, et al. Low testosterone levels are related to poor prognosis factors in men with prostate cancer prior to treatment. BJU Int 2012;110:E541-6.

36. Isom-Batz G, Bianco FJ Jr, Kattan MW, et al. Testosterone as a predictor of pathological stage in clinically localized prostate cancer. J Urol 2005;173:1935-7.

37. Lane BR, Stephenson AJ, Magi-Galluzzi C, et al. Low testosterone and risk of biochemical recurrence and poorly differentiated prostate cancer at radical prostatectomy. Urology 2008;72:1240-5.

38. Botto H, Neuzillet Y, Lebret T, et al. High incidence of predominant Gleason pattern 4 localized prostate cancer is associated with low serum testosterone. J Urol 2011;186:1400-5.

39. Salonia A, Gallina A, Briganti A, et al. Preoperative hypogonadism is not an independent predictor of highrisk disease in patients undergoing radical prostatectomy. 
Cancer 2011;117:3953-62.

40. Teloken C, Da Ros CT, Caraver F, et al. Low serum testosterone levels are associated with positive surgical margins in radical retropubic prostatectomy: hypogonadism represents bad prognosis in prostate cancer. J Urol 2005;174:2178-80.

41. Shaneyfelt T, Husein R, Bubley G, et al. Hormonal predictors of prostate cancer: a meta-analysis. J Clin Oncol 2000;18:847-53.

42. Gann PH, Hennekens CH, Ma J, et al. Prospective study of sex hormone levels and risk of prostate cancer. J Natl Cancer Inst 1996;88:1118-26.

43. Yano M, Imamoto T, Suzuki H, et al. The clinical potential of pretreatment serum testosterone level to improve the efficiency of prostate cancer screening. Eur Urol 2007;51:375-80.

44. Salonia A, Abdollah F, Capitanio U, et al. Serum sex steroids depict a nonlinear u-shaped association with highrisk prostate cancer at radical prostatectomy. Clin Cancer Res 2012;18:3648-57.

45. Porcaro AB, Petrozziello A, Ghimenton C, et al. Associations of pretreatment serum total testosterone measurements with pathology-detected Gleason score cancer. Urol Int 2014;93:269-78.

46. Salonia A, Abdollah F, Capitanio U, et al. Preoperative sex steroids are significant predictors of early biochemical recurrence after radical prostatectomy. World J Urol 2013;31:275-80.

47. Endogenous Hormones and Prostate Cancer Collaborative Group, Roddam AW, Allen NE, et al. Endogenous sex hormones and prostate cancer: a collaborative analysis of 18 prospective studies. J Natl Cancer Inst 2008;100:170-83.

48. Muller RL, Gerber L, Moreira DM, et al. Serum testosterone and dihydrotestosterone and prostate cancer risk in the placebo arm of the Reduction by Dutasteride of Prostate Cancer Events trial. Eur Urol 2012;62:757-64.

49. Platz EA, Leitzmann MF, Rifai N, et al. Sex steroid hormones and the androgen receptor gene CAG repeat and subsequent risk of prostate cancer in the prostatespecific antigen era. Cancer Epidemiol Biomarkers Prev 2005;14:1262-9.

50. Mearini L, Costantini E, Zucchi A, et al. Testosterone levels in benign prostatic hypertrophy and prostate cancer. Urol Int 2008;80:134-40.

51. Ahmadi H, Allameh F, Baradaran N, et al. Circulating sex hormones play no role in the association between sexual activity and the risk of prostate cancer. J Sex Med
2011;8:905-13.

52. Røder MA, Christensen IJ, Berg KD, et al. Serum testosterone level as a predictor of biochemical failure after radical prostatectomy for localized prostate cancer. BJU Int 2012;109:520-4.

53. Imamoto T, Suzuki H, Akakura K, et al. Pretreatment serum level of testosterone as a prognostic factor in Japanese men with hormonally treated stage D2 prostate cancer. Endocr J 2001;48:573-8.

54. Yamamoto S, Yonese J, Kawakami S, et al. Preoperative serum testosterone level as an independent predictor of treatment failure following radical prostatectomy. Eur Urol 2007;52:696-701.

55. Porcaro AB, Petroziello A, Brunelli M, et al. High Testosterone Preoperative Plasma Levels Independently Predict Biopsy Gleason Score Upgrading in Men with Prostate Cancer Undergoing Radical Prostatectomy. Urol Int 2016;96:470-8.

56. Stattin P, Lumme S, Tenkanen L, et al. High levels of circulating testosterone are not associated with increased prostate cancer risk: a pooled prospective study. Int J Cancer 2004;108:418-24.

57. Marks LS, Andriole GL, Fitzpatrick JM, et al. The interpretation of serum prostate specific antigen in men receiving $5 \alpha$-reductase inhibitors: a review and clinical recommendations. J Urol 2006;176:868-74.

58. Cooper CS, Perry PJ, Sparks AE, et al. Effect of exogenous testosterone on prostate volume, serum and semen prostate specific antigen levels in healthy young men. J Urol 1998;159:441-3.

59. Dupree JM, Langille GM, Khera M, et al. The safety of testosterone supplementation therapy in prostate cancer. Nat Rev Urol 2014;11:526-30.

60. Khera M, Crawford D, Morales A, et al. A new era of testosterone and prostate cancer: from physiology to clinical implications. Eur Urol 2014;65:115-23.

61. Morgentaler A. Testosterone and Prostate Cancer: An Historical Perspective on a Modern Myth. Eur Urol 2006;50:935-9.

62. Morgentaler A, Traish AM. Shifting the paradigm of testosterone and prostate cancer: the saturation model and the limits of androgen-dependent growth. Eur Urol 2009; 55:310-20.

63. Morgentaler A, Benesh JA, Denes BS, et al. Factors influencing prostate-specific antigen response among men treated with testosterone therapy for 6 months. J Sex Med 2014;11:2818-25.

64. Khera M, Bhattacharya RK, Blick G, et al. Changes in 
prostate specific antigen in hypogonadal men after 12 months of testosterone replacement therapy: support for the prostate saturation theory. J Urol 2011;186:1005-11.

65. Bologna M, Muzi P, Biordi L, et al. Finasteride dosedependently reduces the proliferation rate of the LnCap human prostatic cancer cell line in vitro. Urology 1995;45:282-90.

66. Arnold JT, Le H, McFann KK, et al. Comparative effects of DHEA vs. testosterone, dihydrotestosterone, and estradiol on proliferation and gene expression in human LNCaP prostate cancer cells. Am J Physiol Endocrinol Metab 2005;288:E573-84.

67. Song W, Khera M. Physiological normal levels of androgen inhibit proliferation of prostate cancer cells in vitro. Asian J Androl 2014;16:864-8.

68. Chuu CP, Kokontis JM, Hiipakka RA, et al. Androgens as therapy for androgen receptor-positive castration-resistant prostate cancer. J Biomed Sci 2011;18:63.

69. Seruga B, Tannock IF. Intermittent androgen blockade should be regarded as standard therapy in prostate cancer. Nat Clin Pract Oncol 2008;5:574-6.

70. Gregory CW, He B, Johnson RT, et al. A mechanism for androgen receptor-mediated prostate cancer recurrence after androgen deprivation therapy. Cancer Res 2001;61:4315-9.

71. Kokontis JM, Hay N, Liao S. Progression of LNCaP prostate tumor cells during androgen deprivation: hormone-independent growth, repression of proliferation by androgen, and role for p27Kip1 in androgen-induced cell cycle arrest. Mol Endocrinol 1998;12:941-53.

72. Mohler JL. Castration-recurrent prostate cancer is not androgen-independent, in Hormonal Carcinogenesis V. New York: Springer, 2008:223-34.

73. Montgomery RB, Mostaghel EA, Vessella R, et al. Maintenance of intratumoral androgens in metastatic prostate cancer: a mechanism for castration-resistant tumor growth. Cancer Res 2008;68:4447-54.

74. Stanbrough M, Bubley GJ, Ross K, et al. Increased expression of genes converting adrenal androgens to testosterone in androgen-independent prostate cancer. Cancer Res 2006;66:2815-25.

75. Isaacs JT, D'Antonio JM, Chen S, et al. Adaptive autoregulation of androgen receptor provides a paradigm shifting rationale for bipolar androgen therapy (BAT) for castrate resistant human prostate cancer. Prostate 2012;72:1491-505.

76. Umekita Y, Hiipakka RA, Kokontis JM, et al. Human prostate tumor growth in athymic mice: inhibition by androgens and stimulation by finasteride. Proc Natl Acad Sci U S A 1996;93:11802-7.

77. Hatzoglou A, Kampa M, Kogia C, et al. Membrane androgen receptor activation induces apoptotic regression of human prostate cancer cells in vitro and in vivo. J Clin Endocrinol Metab 2005;90:893-903.

78. Vander Griend DJ, Litvinov IV, Isaacs JT. Stabilizing androgen receptor in mitosis inhibits prostate cancer proliferation. Cell Cycle 2007;6:647-51.

79. Truong LN, Wu X. Prevention of DNA re-replication in eukaryotic cells. J Mol Cell Biol 2011;3:13-22.

80. Hussain MH, Pienta KJ, Redman BG, et al. Oral etoposide in the treatment of hormone-refractory prostate cancer. Cancer 1994;74:100-3.

81. Schweizer MT, Antonarakis ES, Wang H, et al. Effect of bipolar androgen therapy for asymptomatic men with castration-resistant prostate cancer: results from a pilot clinical study. Sci Transl Med 2015;7:269ra2.

82. Stangelberger A, Waldert M, Djavan B. Prostate Cancer in Elderly Men. Rev Urol 2008;10:111-9.

83. Kaufman JM, Graydon RJ. Androgen replacement after curative radical prostatectomy for prostate cancer in hypogonadal men. J Urol 2004;172:920-2.

84. Agarwal PK, Oefelein MG. Testosterone replacement therapy after primary treatment for prostate cancer. J Urol 2005;173:533-6.

85. Khera M, Grober ED, Najari B, et al. Testosterone replacement therapy following radical prostatectomy. J Sex Med 2009;6:1165-70.

86. Pastuszak AW, Pearlman AM, Lai WS, et al. Testosterone replacement therapy in patients with prostate cancer after radical prostatectomy. J Urol 2013;190:639-44.

87. Morales A, Black AM, Emerson LE. Testosterone administration to men with testosterone deficiency syndrome after external beam radiotherapy for localized prostate cancer: preliminary observations. BJU Int 2009;103:62-4.

88. Sarosdy MF. Testosterone replacement for hypogonadism after treatment of early prostate cancer with brachytherapy. Cancer 2007;109:536-41.

89. Pastuszak AW, Pearlman AM, Godoy G, et al. Testosterone replacement therapy in the setting of prostate cancer treated with radiation. Int J Impot Res 2013;25:24-8.

90. Balbontin FG, Moreno SA, Bley E, et al. Long-acting testosterone injections for treatment of testosterone deficiency after brachytherapy for prostate cancer. BJU Int 2014;114:125-30.

91. Pastuszak AW, Khanna A, Badhiwala N, et al. Testosterone 
Therapy after Radiation Therapy for Low, Intermediate and High Risk Prostate Cancer. J Urol 2015;194:1271-6.

92. American Cancer Society. Cancer Facts \& Figures 2016; American Cancer Society 2016. Available online: http://www.cancer.org/research/cancerfactsstatistics/ cancerfactsfigures2016/index

93. Taylor KL, Hoffman RM, Davis KM, et al. Treatment Preferences for Active Surveillance vs. Active Treatment Among Men with Low-Risk Prostate Cancer. Cancer Epidemiol Biomarkers Prev 2016;25:1240-50.

94. Rhoden EL, Morgentaler A. Testosterone replacement therapy in hypogonadal men at high risk for prostate cancer: results of 1 year of treatment in men with prostatic intraepithelial neoplasia. J Urol 2003;170:2348-51.

95. Kacker R, Hult M, San Francisco IF, et al. Can testosterone therapy be offered to men on active

Cite this article as: Pastuszak AW, Rodriguez KM, Nguyen TM, Khera M. Testosterone therapy and prostate cancer. Transl Androl Urol 2016;5(6):909-920. doi: 10.21037/tau.2016.08.17 surveillance for prostate cancer? Preliminary results. Asian J Androl 2016;18:16-20.

96. Ory J, Flannigan R, Lundeen C, et al. Testosterone therapy in patients with treated and untreated prostate cancer: impact on oncologic outcomes. J Urol 2016;196:1082-9.

97. Ferreira U, Leitao VA, Denardi F, et al. Intermittent androgen replacement for intense hypogonadism symptoms in castrated patients. Prostate Cancer Prostatic Dis 2006;9:39-41.

98. Kaplan AL, Hu JC, Morgentaler A, et al. Testosterone therapy in men with prostate cancer. Eur Urol 2016;69:894-903.

99. Morales A. Effect of testosterone administration to men with prostate cancer is unpredictable: a word of caution and suggestions for a registry. BJU Int 2011;107:1369-73. 